\title{
Taking a holistic view of the biblical perspectives on childlessness: Implications for Nigerian Christians and the church in Nigeria
}

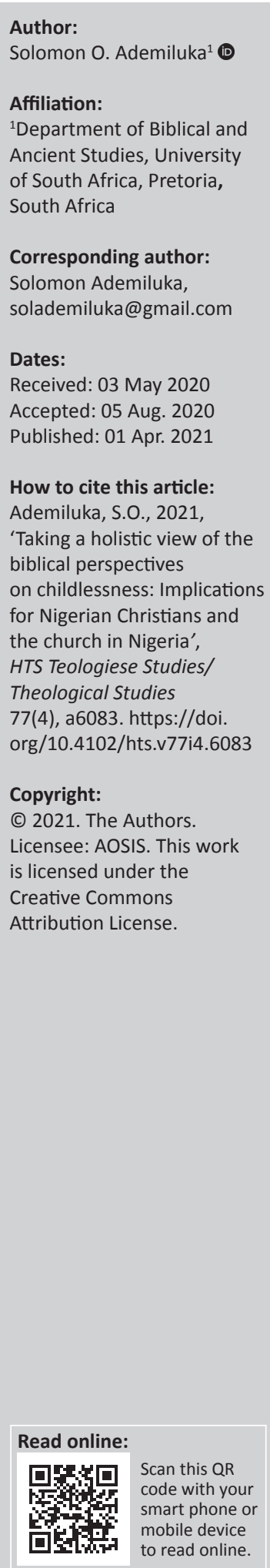

The belief amongst some Christians that it is God's plan for everyone to have children, and that barrenness is a punishment from God is apparently derived from the Old Testament (OT). This article attempts a holistic study of the biblical perspectives on childlessness with a view to ascertain whether procreation is a moral responsibility of every individual. The target group includes Nigerian Christian couples suffering from infertility. The article employs the descriptive and exegetical methods. The study revealed that the belief that the OT views barrenness as caused by sin and a punishment from God was erroneous. A critical examination of the relevant texts revealed that infertility is a natural phenomenon, and God gives children as a blessing but not necessarily to every individual. In the New Testament (NT), the attitude towards childlessness is characterised by the concept of 'alternative family models', by which some Christians could adopt children whilst others might choose to be celibate, being satisfied with their membership of the community of believers. Paul's teaching in 1 Corinthians 7 clearly mitigates natural childbearing, and thus negates any attitude of desperation for bearing children. In the Nigerian context, this interpretation necessitates a change of attitude towards infertility. The church has to develop a theological reconstruction with regard to procreation in marriage, in a manner that will assure Christians that a childless marriage is not lacking in any way.

Contribution: The article is a contribution in the area of theology of marriage, and thus of high relevance in contemporary Africa, particularly Nigeria, where people, including Christians, still have the traditional belief that it is morally mandatory for everyone to have biological children.

Keywords: infertility in Nigeria; desperation for children; Paul on celibacy; marriage and procreation; childlessness and self-acceptance.

\section{Introduction}

Infertility has been identified as a global health problem, influencing the lives of roughly $10 \%$ of the world's population (Schones 2019:1). Writing with regard to the United States, Monroe and Monroe (2005) state that 'one in six couples struggles with infertility. One in four couples over the age of thirty-five struggles with infertility' (p. 50). In a study conducted by Adeyanju and Ayandiran (2013) in southwestern Nigeria, 'it was discovered that the prevalence of female infertility was about 45\%' (cited in Ademiluka 2019a:1). Many Christians believe that the bible teaches that children are a gift from God, and it is his plan for everyone to have them. Childlessness is, therefore, often seen as God's punishment for certain sins that the barren must have committed. This is the perspective that is sometimes derived from the Old Testament (OT) if the relevant texts are not critically and adequately scrutinised, but which unfortunately has largely controlled Christian attitude towards the problem of childlessness. In the modern world, this belief seems to accentuate the burden that is usually associated with childlessness, as affected persons are made to sense that something is wrong about themselves (Rohlin 2006:1). Many infertile Christians today ask questions as to whether God is punishing them for certain 'unconfessed sins in their lives' (Christian Medical and Dental Associations [CMDA] 2018:14). Thus, childlessness affects one's spirituality, which makes it a 'topic worth pursuing in a variety of fields [particularly] ... biblical studies' (Schones 2019:1). To this end, this article attempts a holistic study of the biblical perspectives on childlessness with a view to ascertaining 'whether procreation is a moral responsibility for married couples, whether it is the primary purpose of marriage, and whether a childless marriage is, as such, an incomplete marriage' (Magnuson 2000:26). It also examines the implications of the study for Nigerian Christians and the church in Nigeria. The target group 
included Nigerian Christian couples suffering from infertility. The article employs the descriptive method for the study of childlessness as it affects Nigerian Christians. It applies the exegetical approach for the examination of the relevant texts. The work begins with a discussion of the Christian attitude towards childlessness in Nigeria, from where it proceeds to the OT perspective. It then examines the attitudes towards childlessness in the New Testament (NT), and finally, the implications of the study for Nigerian Christians and the church in Nigeria.

\section{Christian attitude to childlessness in Nigeria}

In Nigeria, as in most parts of Africa, marriage is constituted primarily for the purpose of procreation. Mbiti (1969) states that in Africa:

$[T]$ he supreme purpose of marriage is to bear children to build a family [hence] if there is not yet a child in the marriage people do not consider it to be a marriage. (p. 132)

In fact, 'the indissolubility of marriage is conditioned to its fruitfulness; the birth of a child marked the "consummation" of the marriage' (Marriage \& Family 1988:online). For the African, for one to die without having children means to 'be completely cut off from the human society, to become an outcast and to lose all links with mankind' (Mbiti 1969:133). The belief that one must have children may explain the general attitude towards the barren in many African communities. In the words of Egede (2015):

[C]hildless couples are faced with a cosmological dilemma or tragedy ... This is because ... procreation is a group survival issue for ... the primordial public and the involuntary childless in not being able to reproduce may be seen to threaten the existential nature of their primordial public. (p. 51, cited in Ademiluka 2019a:5)

It must be pointed out, however, that in Africa it is the barren woman who is always at the receiving end of suffering on account of childlessness. This arises from 'the pathology that sees men as fertile at all times while women are claimed to be infertile' (Baloyi 2017:2), thereby perpetuating 'the idea that infertility and involuntary childlessness are female problems' (Egede 2015:62). Moreover, in African thought a woman is 'needed as a child-bearer and derived her social status and her indispensable value from this position' (Baloyi 2007:2). To this end, the condition of a barren woman can be very miserable. Mbiti (1969) states that the infertile woman:

[B] ears a scar which nothing can erase. She will suffer for this; her own relations will suffer for it. It is an irreparable humiliation for which there is no source of comfort in traditional life. (cited in Ademiluka 2019a:5)

In some places, childless women are objects of public ridicule; they are 'despised, scorned, pitied and shunned' (Egede 2015:56).

It is therefore understandable why Nigerian women who have difficulty in getting pregnant after wedding can go to any length to seek remedy. When a couple faces this condition, their 'first point of call is usually the hospital' (Nwosu \& Onwe 2015:43). If the problem persists, they begin to seek spiritual help, particularly for the woman, from traditional healing homes and the so-called spiritual churches. Abasili (2011) opines that ' $[n]$ owadays a good number of women in this predicament seek the help of orthodox medical practitioners [rather than] ... visit traditional healers' (p. 566). However, as Ademiluka (2019a) rightly points out:

$[I] \mathrm{t}$ is common that even today, in Nigeria most barren women do not discriminate in the choice of the places they visit for help. Irrespective of religion and denomination, most of them visit traditional healers when orthodox medicine and praying in the Christian way have been employed to no avail. (p. 6)

As Amole (2011) puts it, Nigerian Christian couples who are unable to conceive often go:

$[B]$ eyond the ambit of their Christian faith ... going from churches to churches seeking signs and wonders, the conjuring of spirit, consulting of the Babalawo (Ifapriest), combating with witches and wizards. (Online)

It is significant to note that the Nigerian Christians' desperation to change their status derives not only from the traditional attitude towards childlessness but also from the erroneous conception that the Bible views barrenness as a consequence of sin, and is therefore a punishment from God. (This view is discussed in detail in the section below) Commenting on this point, Ryan (2005) aptly states:

The interwoven symbolisms of judgment, blessing, and mystery [in some bible references] yield a confusing answer to the suffering occasioned by infertility. Infertile women, in particular, are tempted to blame themselves ... for their present inability to conceive or bear a child; some believe that they are being punished by God for their earlier ambivalence about having children. (p. 69)

Because of this view from the OT, many infertile Christians believe it is God's will for everyone to have children. Hence, in their desperation some conclude that God is punishing them for 'unconfessed sins in their lives or that their prayer lives are insufficient' (CMDA 2018:14).

So far, the church in Nigeria is yet to develop a profound theology towards the problem of childlessness. Apart from the periodical prayers for women seeking the fruit of the womb in some denominations, attention towards the issue of 'barrenness is mostly conspicuous in the Pentecostal churches' (Ademiluka 2019a:6). The belief of these churches on childlessness still conforms largely to the OT belief that barrenness is a curse, for which reason their methods focus mainly on getting the curse removed. 'Barrenness is caused by witches, envious relatives, demons and the mermaid who lives under the sea' (Asamoah-Gyadu 2007:2). They seem not to believe that 'some couples may be destined [by God] never to have children of their own' (Asamoah-Gyadu 2007:442). With faith even a woman who is past the childbearing age, such as in the case of Sarah, can still give birth. To this end, 
many Pentecostal pastors hold that 'the phenomenon of barrenness must ... submit to Jesus' (Holter 2014:435), the belief which is often manifested in the literature of their prayers. For example, Pastor Enoch Aminu, founder of Pure Fire Miracle Ministries, would pray thus:

$[B]$ arrenness must die in Jesus' name; unfruitfulness must die in Jesus' name. By the grace of God upon my life I bind every curse upon your life and set in motion the blessing of fruitfulness upon your life; in Jesus' name. (Asamoah-Gyadu 2007:445)

Oftentimes, some ingredients like olive oil, consecrated water and certain concoctions are given to women seeking the fruit of the womb to drink along with prayers (Asamoah-Gyadu 2007:447). Another method includes the reading of psalms into olive oil or water to be drunk by infertile women (Ademiluka 2012:37).

Thus, as earlier mentioned, the response of the church in Nigeria to the problem of childlessness still reflects the belief that everyone must receive the gift of biological children from God, and if this does not happen the barren must be under some curse, which represents one aspect of OT tradition. In the next section, the article examines relevant texts in order to bring out the OT view on childlessness.

\section{The Old Testament on childlessness}

The OT view of childlessness is better understood against the background of attitude towards children in the ancient Near East. Just as in the African culture, in the ancient Near East:

While marriage was an important rite of passage for a woman ... it seems that childbirth surpassed this as the most important rite of passage ... [M]arriage was not legitimated until the presence of the first child, thus the consummation of the union was not complete until it produced offspring to carry on the father's lineage. (De-Whyte 2014:35)

This means that, as in Africa, in this culture also the purpose of marriage was the perpetuation of the husband's lineage, hence the preference for male children, as in most patriarchal cultures (De-Whyte 2014:33). In the ancient Near East, therefore, an infertile woman was given little regard because she would not be providing an heir for her husband (De-Whyte 2014:34). But the status of a barren woman was worse than that. According to Jamieson, being a mother 'confers a high degree of honor in the East, and the want of that status is felt as a stigma and deplored as a grievous calamity' (Bible Hub 2017, cited in Ademiluka 2019b:5). Ellicott's Commentary states that 'there is an Oriental proverb that a childless person is as good as dead' (Bible Hub 2017, cited in Ademiluka 2019b:5). Commenting on ancient Israel, Kösternberger (2004) affirms that 'the most important duty of a married woman ... is the begetting of offspring for her husband otherwise she will be viewed as a disgrace' (cited in Abasili 2015:589). The Israelite woman carried the additional expectation of fulfilling 'the promise to Abraham, and bringing forth that seed in which all the families of the earth were to be blessed' (Bible Hub 2017, cited in Ademiluka 2019b:5; cf. Moss \& Baden 2015:29).
It is against this background of passionate desperation for children that the 'barren mother stories' (Scott 2011) cited in the Hebrew Bible (HB) can be understood. It is also from the narratives of these women, such as Sarah (Gn 16:1-6), Rachel (Gn 30:1-6) and particularly Hannah (1 Sm 1:1-20), that certain beliefs about childlessness are derived. The approach here is to identify motifs that are common to the narratives, which indicate the beliefs of the narrator and their audience about childlessness. The Hannah narrative is the most detailed of them. The narrator begins by introducing Elkanah the Ephraimite with his two wives, Hannah and Peninnah. The latter has children but the former has none. Every year, Elkanah goes to the annual festival at Shiloh with his family. At the ceremonial meal, Elkanah usually gives 'a double portion' to Hannah 'because he loved Hannah' (1 Sm 1:5, ESV, NIV ${ }^{1}$; cf. Berlin 2004:227, cited in Ademiluka 2019a:3). As it is often the case in polygamous homes, Hannah's special treatment meted by Elkanah induced Peninnah's jealousy, as her taunts made Hannah miserable all the time. At this particular festival, Hannah did not participate in the meal, but after that session, she went into silent prayer to God. Perhaps because this manner of prayer was unusual in ancient times, Eli the priest suspected that she was drunk (Berlin 2004:230). Hannah was not drunk, but was 'desperately pouring out her heart to God asking for the gift of a son' (Ademiluka 2019a:3; cf. vv. 11,15). Hannah did not just ask for a son but also made a vow to consecrate the child to God as a Nazirite (cf. Nm 6). God answered her prayer and 'in due time Hannah conceived and bore a son, and called his name Samuel' (v. 20).

Next to the Hannah story in details is the narrative of Sarah and Hagar (Gn 16). In her desperation to have a child, Sarah offers Hagar, her maid, to her husband Abraham for intercourse so that she may obtain children through Hagar (v. 2). Abraham accepts the offer, and Hagar gets pregnant by him (vv. 3-4a). Similar to Hannah's encounter with Peninnah, rivalry ensues between Sarah and Hagar so much so that the latter has to flee from home. She later gives birth to a son and names him Ishmael (vv. 4b-6). As earlier hinted, the desperation of Sarah and Abraham was well-placed in a society where people cared about who would be inheriting their legacy. In the absence of a child of their own, Abraham and Sarah had put measures in place for an heir in the person of Eliezer of Damascus, Abraham's servant (Gn 15:2). This decision was in line with the ancient Near Eastern custom 'in which childless masters would adopt people as heirs ... to care for their adoptive parents and perform their burial and mourning rites when the time came' (De-Whyte 2014:103). Very similar to Sarah's narrative is the case of Rachel in Genesis 30:1-6. Rachel is Jacob's second wife and rival to her sister, Leah. Rachel has delay in bearing a child and becomes jealous of her sister; in desperation, she demands from Jacob, 'Give me children, or I shall die' (v. 2, RSV). But Jacob tells her that it is God who gives children. Like Sarah, Rachel gives her maidservant, Bilhah, to her husband in

1.The Bible references used in this article are abbreviated as follows: English Standard Version (ESV); New International Version (NIV); Revised Standard Version (RSV). 
order to have children through her (v. 4). The action of Sarah and Rachel in using their slaves as surrogates was also well-attested 'in ancient Near Eastern family law' (Fletcher 2006:online). In that custom, 'if your wife cannot have children, you can have children by your wife's slaves, and the child becomes yours' (Klein 2008, cited in Ademiluka 2019b:6). Loumagne (2015) also states that:

$[T]$ he practice of surrogacy was actually an accepted practice in ancient Near Eastern cultures as [it] ... allowed a barren woman to regularize her status in a world in which children were a woman's status. (p. 1)

Wenham (1994:72) opines that Sarah's and Rachel's action was a resort to surrogate marriage. Also worthy of mention amongst barren mothers are Isaac's wife, Rebekah (Gn 25:21), Manoah's wife, the mother of Samson (Jdg 13:2-5) and the Shunammite woman (2 Ki 4:16-17).

As regards the theological purpose of the narrators of these stories, readers would wonder if the women in question were the only barren women in ancient Israel. It is most unlikely! Of what purpose, then, was the special focus on them? As Moss and Baden (2015) observe:

[T] hese five women [are not] only the ones who are marked out as barren, but they are also the only ones for whom God's role in bringing about their fertility is explicitly stated. (p. 59)

It is also noteworthy that these special women gave birth to sons who became extraordinary national figures. Isaac, Jacob and Joseph were the patriarchs through whom the promise of a great nation to Abraham was realised (Gn 12:2). Samson was the first deliverer of Israel from the Philistines (Jdg 13:5), and 'Samuel, the great judge and prophet, is also the midwife of the Israelite monarchy' (Moss \& Baden 2015:59). Therefore, in a way, the infertility of these women was secondary to the biblical authors, their main concern being to demonstrate the involvement of God in the emergence of the nation Israel:

These stories stress God's participation not only in the process of individual conception, but in the process of national conception, in the birth and sustenance of Israel as a people. (Moss \& Baden 2015:60; cf. CMDA 2018:15; Rohlin 2006:1)

However, for the purpose of this article, it is important to point out that the barren mother narratives indicate that God is responsible in one way or the other for the women's barrenness. For instance, in Genesis 16:2 Sarah exclaimed that 'the Lord has prevented me from bearing children' (RSV). Jacob's response to Rachel likewise shows that God was believed to have 'denied [her] the fruit of the womb' (Gn 30:2). In the case of Hannah, the narrator declares that 'the Lord had closed her womb' (1 Sm 1:5). The biblical authors, then, project the belief that 'it is God's prerogative to give children and, in some cases, to prevent ... conception and birth' (Ekeke \& Uchegbue 2010:207; cf. Ps 127:3; Is 44:24; 49:5). The authors therefore conceived the idea of an inextricable connection between barrenness and sin; God withheld offspring from these women because of their sins. Thus, 'the theological intention of these texts is clear [namely] infertility as punishment, just like children as blessing, is the work of Israel's God' (Moss \& Baden 2015:43). In this light, Byron (2010:21) observes that every one of these stories describes how barrenness finds its resolution in divine intervention. In addition to this, in Exodus 23:26 (cf. Dt 7:14):

[T] he negative image of childlessness is communicated by promises declaring that, if Israel is faithful to God, there will be no barrenness in the land, suggesting that childlessness is evidence not of the blessing of Yahweh but a curse. (Byron 2010:21)

This belief seems to be well-known in the ancient Near East, as Loumagne (2015) asserts that 'in ancient Near Eastern cultures childlessness was regarded as a virtual sign of divine disfavor' (p. 1).

Even in modern times, many people still have this belief that infertility is a result of divine punishment. However, a critical examination of the barren mother narratives and other relevant texts reveals other strands of thought present in the HB and OT traditions that point towards the contrary. To begin with, when infertility is considered as an affliction, there are texts that explicitly describe afflictions as divine punishment. For instance, in 2 Chronicles 26:19-20 King Uzziah is afflicted with a skin disease for offering incense in the sanctuary, which was the prerogative of the priests. Gehazi, Elisha's servant, suffered the same disease for asking for money for his master's free healing services (2 Ki 5-27). But in some other texts similar afflictions are faced by people naturally, not as a punishment. An example can be seen in Leviticus 13-14 where the laws on skin disease align it with events such as sex and childbirth, not with any wrong doing. It is also noteworthy that righteous individuals are reported to have fallen ill as humans often do, not for having committed any sin, for example prophet Elisha (2 Ki 13:14), King Hezekiah (2 Ki 20:1), King Josiah (2 Ki 23:29) and Daniel (Dn 8:27). It may be correct to say, then, that because certain ailments sometimes occurred as a divine punishment, biblical authors 'came to believe that such [ailments] were always such [that is] they were simply extrapolating from the known to the unknown' (Moss \& Baden 2015:45). The assumption that infertility was always a divine punishment subsumes under this attitude. Of course, there are a few cases where infertility is explicitly a divine punishment. One instance can be seen in Genesis 20 where God makes all the women in the court of Abimelech, the King of Gerar, barren on account of the king's seizure of Sarah, Abraham's wife. Another one concerns Michal who was barren because she ridiculed her husband, David, for dancing in the presence of the Lord (2 Sm 6:23). On the contrary, the cases of Sarah, Rachel and Hannah discussed previously are different because there are no wrongs explicitly mentioned that any one of them had committed to justify barrenness as punishment. In this light:

[I]nfertility falls in a class of biblical misfortunes, including disease, famine, sickness, and death, that share certain common features ... [They may occur] as divine punishment, or without 
any explanation whatsoever ... In other words, we are dealing ... with two distinct phenomena presented in a common form [namely] divine intervention and mere happenstance presented in the form of infertility (or sickness, or famine, or death). Death presents perhaps the best analogy: divine punishment can, at times, take the form of premature death, just as at times it can take the form of infertility. But we would be mistaken to read all premature deaths as divine punishment, just as we would be mistaken to read all cases of infertility as divine punishment. (Moss \& Baden 2015:49-50)

However, the OT world did not have that clear distinction between the natural and the supernatural. For the ancient Israelite:

$[N]$ o part of life was totally divorced from the [religious] realm ... [E]ven those misfortunes we might today call 'natural' are addressed not with medicine ... but rather by appealing to God. (Moss \& Baden 2015:50)

In this way, in the absence of biological information about conception, those in the ancient world put the responsibility for fertility on 'the ultimate unknowable entity [that is] God' (Moss \& Baden 2015:53; cf. Jr 1:5; cf. Ps 139:13; Job 31:15; Ec 11:5).

Nonetheless, OT perspective on childlessness cannot be concluded without discussing the imperative to 'be fruitful and multiply' (Gn 1:28). According to the priestly account of creation, these were God's first words to mankind. The same words are repeated to Noah after the Flood (Gn 9:1, 7). They appear in similar forms again to Abraham (17:6) and to Jacob (35:11). In Jewish tradition, this text is 'considered to be a moral imperative, a religious duty that is meant to channel sexual passion for the purpose of the perpetuation of humankind' (Magnuson 2000:27). In the words of Moss and Baden (2015), for generations it has been understood as:

$[A]$ divine imperative to each and every individual to produce offspring ... If one chooses not to bear children, then one could be seen as violating a direct divine command ... If one is unable to bear children, one is considered cursed (p. 72)

In Christian theology, 'the concept of procreation as a moral command is expressed in terms of a creation mandate' (Magnuson 2000:27). Wenham (1987), for instance, indicates that, following Gn 1:27 ('male and female he created them'), the imperative to 'be fruitful and multiply' in verse 28 is a pointer to the 'divine purpose of marriage' (p. 33). Karl Barth (1956-1975) interprets Genesis 1:28 in terms of 'the propagation of the race [which was] an unconditional command [until] the advent of Christ' (cited in Magnuson 2000:27).

However, this is the impression derived from reading Gn 1:28 as a command rather than a blessing. As Moss and Baden (p. 72) rightly observe, these words are not a command, given the fact that neither Noah nor Jacob had children again after they received the words; in which case they would have been guilty of disobeying the divine instruction. It is also noteworthy that the same words 'Be fruitful and multiply' are said to the fish of the seas (Gn 1:22), which are 'obviously not intended to become responsible for their reproduction' (Daube 1977:3). Whereas if the text is read as a blessing, the question of obedience or disobedience does not arise; instead, the responsibility resides with God to fulfil his words. As Magnuson (2000) puts it:

$[W]$ hile human beings can demonstrate an openness to procreation, it is God alone who creates life. Since life is a gift from God (Psalm 127:3), understanding procreation as a command may place too much emphasis upon human procurement of God's blessing. (p. 28)

Furthermore, the blessing of children in Genesis 1:28 should not be read as applying to individuals or something that is passed down genetically from Adam or Noah (Moss \& Baden 2015:75). For if it were so understood, there would have been no need to repeat it to Abraham and Jacob. In this way, the blessing is best understood in light of its functional parallel in Genesis 12:2: 'And I will make of you a great nation, and I will bless you, and make your name great, so that you will be a blessing' (RSV). In other words, the promise of children was not necessarily for Abraham and Jacob as individuals, but had in mind 'the people who, far in the future, will descend from those who are blessed' (Moss \& Baden 2015:75). Monroe and Monroe (2005) succinctly put it as, 'Children are a blessing, but they are not promised to us individually' (p. 50).

On the contrary, some have insisted that Genesis 1:28 should be understood in the context of marriage, as 'we cannot think of ... of procreation in abstraction from marriage' (Murray 1957, cited in Magnuson 2000:27). As earlier mentioned, Wenham (1987) also believes that Genesis 1:28, coming after Genesis 1:27, indicates the 'divine purpose of marriage' (p. 33). As Magnuson points out, Wenham here echoes the popular 'Christian thinking ... that procreation is the primary purpose of marriage' (p. 31). For instance, both Augustine and Aquinas propounded this view, relying on Genesis 2:18 which states that woman is created as a suitable helper for man. Brunner (1937) opines that 'it is an essential part of marriage that it should be fruitful [and if not] it certainly is not a normal complete marriage' (cited in Magnuson 2000:31). Nevertheless, this view may not be correct when it is weighed against critical theological reflection, particularly on Genesis 2:18-24, which many have 'recognized as a narrative on the divine institution of marriage and the beginning of human family' (Jerome (2016:528). In the Jahwist account of creation (Gn 2:4b-25), verse 18 is 'the evaluation of the creation [which] identifies a problem with [it] up to this point - human aloneness - and moves to resolve it' by providing a companion for the man (Birch et al. 2005:46). Hence, Wenham (1994) opines that Genesis 2:18 'explores the nature of companionship within marriage' (p. 62). The man's exclamation upon seeing the woman, 'This at last is bone of my bones and flesh of my flesh' (v. 23, RSV), confirms the view that woman was made for man for the purpose of companionship. This is because ' $[h]$ is delight is that of seeing a complementary companion, not because he is given someone who can bear him children' 
(Magnuson 2000:33). This interpretation has been supported by many theologians. For example, even Augustine (1988), who argued for procreation as the purpose of marriage, as earlier seen, recognised the value of companionship when he declared that 'although marriage and sexual union are for the purpose of procreation, even the marriage that is unable to produce children does not cease to be a valid marriage' (cited in Magnuson 2000:32). As Magnuson (2000) rightly concludes:

$[T]$ here is a natural connection between marriage, sexual union, procreation and the nurturing of children [but there is also a need] for a balanced understanding of [these acts in order to avoid] an undue emphasis on each act of sexual union. (p. 33)

In other words, there should be no undue emphasis on procreation; there can be marital union without procreation.

Thus, in the OT, childlessness is considered a great misfortune, and because of the absence of modern knowledge about conception, infertility was thought to be a punishment from God. This belief, however, does not represent the teaching of the OT on childlessness; like every other mishap, infertility happens naturally. The OT perspective is that God gives children as a blessing that is not necessarily meant for every individual. Marriage is primarily for companionship, not procreation. Next, the essay considers childlessness from the NT perspective.

\section{Attitudes to childlessness in the New Testament}

In the NT, it is only the story of Elizabeth the wife of Zachariah in Luke chapter 1 that is similarly to those of Sarah, Rachel and Hannah. Scholars also often mention Priscilla and Aquila her husband who probably had no children (Rm 16:3-5; Ac 18; 1 Cor 16:19; 2 Tm 4:19) (Muasya 2018:10). However, there are indications that the NT apparently reflects 'a larger social matrix in which families were made and not begotten' (Moss \& Baden 2015:144). In this regard, in an attempt to reconcile the divine and human parentage of Jesus, many have interpreted the relationship between him and Joseph from the perspective of adoption. Right from the beginning of their gospels, Matthew and Luke take time to prove that Jesus was of the Davidic lineage. For example, this plan is made clear by Matthew in his account of the genealogy of Jesus (Mt 1:1, RSV). The author at several places also uses the title 'son of David' in the book for Joseph (1:20) and for Jesus $(9: 27 ; 12: 3,23 ; 15: 22 ; 20: 30-31 ; 21: 9,15)$. But in the same breath (vv. 16, 18-24), he 'proclaims that Mary, Joseph's betrothed and Jesus' mother, was a virgin, precluding any notion of Joseph being Jesus' [biological] father' (Levin 2006:417; cf. Lk 1:26-27, 32). The concept of Jesus' Davidic descent is not limited to Matthew and Luke but well-attested 'within the literature of the New Testament and $\ldots$ the early Christian community that produced that literature' (Levin 2006:417; cf. Mk 10:47-48; 12; 35-37; $\operatorname{Rm} 1: 3 ; 2 \operatorname{Tm} 2: 8 ; \operatorname{Rv} 3: 7 ; 5: 5 ; 22: 16)$.

In addressing this apparent contradiction of Jesus being son of God and son of David, most commentators have suggested that Jesus was considered Joseph's son by adoption. 'By marrying Mary, Joseph adopted Jesus and raised him as his own' (Moss \& Baden 2015:154; cf. Mt 1:24-25; 13:55; Lk 2:21-22). Levin (2006) states that, 'the general assumption is that Jesus inherited his Davidic status by means of adoption' (p. 422). Nevertheless, the question remains as to the background against which the evangelists conceived the idea of Jesus' adoption. Some 'have made recourse to Jewish parallels' (Moss \& Baden 2015:153), but it seems that adoption as a legal institution, though 'widely used throughout the ancient world, it is ... hardly mentioned in the Hebrew Bible' (Byron 2010:34; cf. Levin 2006:423). Scholars point out that though there are several stories that seem to indicate adoption, such as Abraham's adoption of Eliezer, Moses's adoption by Pharaoh's daughter (Ex 2:10) and Esther's adoption by Mordecai (Es 2:7), 'almost all of these are cases of adoption within the existing family ... and in no case can it be shown that such an "adoption" had any legal consequences' (Levin 2006:423, original emphasis). Therefore, as concluded by Levin (2006):

$[T]$ here is nothing in Jewish law, in either the Hebrew Bible or in later Halakhah, which can be seen as the model by which Jesus, Son of God, could have been considered the legal, but not genetic, heir to the Davidic throne. (p. 425)

Levin has argued extensively that the appropriate context within which to understand Joseph's relationship to Jesus is the practice of adoption in the early Roman empire of the first century CE, which 'the authors and audiences of Matthew and Luke would have been most familiar with' (p. 425). According to Moss and Baden (2015), in spite of the high rates of infant mortality, the Romans, particularly the aristocrats, did not favour large families, the outcome of which was that prominent Roman families were often left without heirs. The solution to this predicament for many was adoption. In the Roman world, adoption was not about child welfare but was concerned with the 'continuation of the familial line [and] the transference of property, wealth, and status. Like natural sons ... adopted sons were legal heirs' (Moss \& Baden 2015:145). A most famous instance of Roman adoption was that of Octavian. Octavian was Julius Caesar's grand-nephew and adopted son who later became Caesar Augustus (Levin 2006:427; Moss \& Baden 2015:145). Of course, Joseph's 'adoption' of Jesus is not an exact cognate to the Roman law but the two share clear affinities. According to Levin (2006):

[T] he adoption of a relative, in this case of the son of Joseph's betrothed, would have been only natural to a Roman. [As in the Roman system,] the purpose of the adoption was not to give the child a home, but rather specifically to make him an heir to the Davidic royal line. (pp. 431-432)

In reconciling Jesus' divine sonship with his Davidic descent, then, Matthew and Luke drew upon the context with which they were familiar. Hence, Levin (2006) concludes that:

[T] he authors of both Matthew and Luke, faced with the dual traditions of both Jesus' Davidic Messianity and his Divine Sonship, dealt with the obvious contradiction in the only way 
that would have seemed natural to a subject of the Julio-Claudian and Flavian Principate [namely] by assuming that Jesus, Son of God, could have been adopted into the royal line of Israel, all the while retaining his status as theou huios [son of God]. (p. 434)

If the early Christians understood Jesus' being Joseph's son in terms of adoption, it means that they were familiar with the practice of raising families not only biologically but also through adoption. Therefore, unlike in the OT where childless couples had to rely virtually on divine intervention, in the NT Jewish world infertility did not seem to be considered an enormous problem, as adoption could be used 'for circumventing the challenges of childlessness' (Byron 2010:35). In fact, as will be seen in Paul, for some, procreation was not at all a matter of necessity but of choice.

In 1 Corinthians chapter 7 , members of the Corinthian church had written to Paul inquiring if 'it is well for a man not to touch a woman' (v. 1, RSV). The RSV translates me aptesthai (not to touch) literally, thereby giving the impression of sexual intercourse, but other versions like the NIV render it as 'not to marry'; which is more appropriate in view of verse 2, where the writer advises everyone to marry 'because of the temptation to immorality' (Ademiluka 2019c:5). In their inquiry to Paul, then, the Corinthians 'had voiced a wish for abstinence from marriage [that is, a] ... desire for celibacy' (Baumert 1996:25). From verses 2-9, Paul further explains that the Christians should marry to avoid sexual immorality, as in marriage husband and wife can rightfully enjoy sexual intercourse (vv. 2-5). Paul wishes that all could remain single like himself but because they may not have the gift of self-control as he, they may go ahead and marry (vv. 7 -9). Therefore, for Paul, 'marriage was permissible for those for whom abstinence was simply too hard' (Moss \& Baden 2015:171). In other words, for him the ground for marriage is not procreation but to avoid sexual immorality. Thus, whilst Paul does not mean that marriage is a sin (v. 28), he also does not view it as compulsory; for him, celibacy is preferable. As summarised by King (2011):

Paul's view on marriage involves two basic propositions [namely] the single life is better than the married life, but the married life is better than fornication ... Paul's advice, then, is that those who can handle celibacy and not be tempted by fornication should opt for the single life, but those who do not possess the necessary self-control should opt for marriage so as to avoid fornication. (p. 5)

Some interpreters opine that Paul prefers celibacy for Christians on two grounds (King 2011:5-7; Reed 2013:73). First, it is better to remain single in view of the imminent eschaton (v. 26), and second, celibacy will enable them to be fully devoted to God's service (vv. 32-34). In verse 26, Paul claims that there is a 'present crisis' (enestosan anagken) in Corinth, which is explained in verse 31 in terms of 'the form of this present world ... passing away' (RSV). But it should be noted that the reference to the eschaton here is applicable only to the betrothed members of the Corinthian church (vv. 25-40). Paul says that in view of the imminent end of the world, ${ }^{2}$ it is preferable for them not to consummate marriage with their partners; however, they are free to do as they wish (Ademiluka 2019c:8; King 2011:6). Moreover, Paul has made it clear that he was single; which could not be linked to his view of the eschaton. Throughout the chapter, he has not hidden his preference for the celibate life for Christians (vv. 1, 7-8, 38). Therefore, the principal reason for Paul's preference is found in verses 32-34. Celibacy is preferable for Christians because it will enable them to be fully devoted to God's service, free from worldly anxieties. Whilst the unmarried Christian is concerned about the affairs of the Lord, the married one is anxious about worldly affairs, particularly how to please his or her spouse.

Paul's attitude to marriage and sex is best understood against his own ancient religio-philosophical context. Moss and Baden (2015) situate Paul's preference of celibacy over marriage in later stoicism and Jewish asceticism. For instance, Paul's idea that marriage was necessary for those who could not control themselves sexually 'and would need release echoed the sentiment of ancient medics and Romans in general, for whom an excess of blood boiled sperma required a legitimate outlet' (Moss \& Baden 2015:189). Hence, in choosing marital affairs over patronage of prostitutes, Paul blended together biblical morality and 'Stoic sexual ethics or Jewish asceticism' (Moss \& Baden 2015:190). Plato's well-known idea of marriage and sex as a distraction must also have influenced Paul's relation of matrimony to worldly anxieties (Moss \& Baden 2015:190); the suggestion which seems to be reflected by Keener (1993) when he states that:

[A] number of groups of philosophers and minor [Jewish] religious sects ... advocated celibacy or the rejection of marriage. [To them] marriage is distraction and should never be undertaken by the wise man except in the rare instances where one might find a spouse equally devoted to the philosophic life. (p. 466)

In regard to childlessness, it is pertinent to note that Paul advocates for 'sex as release' (Moss \& Baden 2015:191) and for protection against immorality; and as Reed (2013) rightly observes, throughout 1 Corinthians $7, ‘[n]$ ever once does Paul mention procreation as the purpose of marriage' (p. 71). For Paul, then, the purpose of sex within marriage is for prophylactic and ethical purposes, 'not the production of children' (Reed 2013:71). In other words, allowing 'for distinctive valuations of each, Paul systematically works to sever sex, marriage, and procreation from one another' (Moss \& Baden 2015:191). Moss and Baden (2015) thus put it succinctly as:

Procreation is not in and of itself important enough to require engaging in sexual intercourse. The preferential course for a follower of Jesus is celibacy, and with this realignment of the relative status of marriage there necessarily follows $a$ demotion of the importance of natural childbearing. (p. 191, [author's own italics]; cf. CMDA 2018:14)

2.Some claim that by 'the present crisis' Paul points to a historical crisis in grain shortages that led to widespread famine throughout the Roman Empire at that time (see Reed 2013:77). 
By means of the phrase in italics, the authors are saying that preference for celibacy implies a choice of life without biological children. But perhaps in consideration of Paul's teaching on the marital relationship and the family in his other epistles (e.g., Eph 5:22-26:9), they are quick to point out that Paul's position is not necessarily advocacy:

[F]or singular isolated bachelorhood;[rather,] he proposes the unity of the fraternal community - the family of believers ... as a family model, [thereby laying] the groundwork for models of parenting [other] than [the] biological. (Moss \& Baden 2015:191)

Paul's idea of alternative family models is in line with Jesus' recognition of the community of his followers over his biological relatives (Mk 3:31-35; cf. 10:29-30) and, perhaps, his favourable statement about people who 'have renounced marriage because of the kingdom of heaven' (Köstenberger 2011:5; cf. Mt 19:12, NIV).

By way of summary, given the earlier conclusion that Jesus' sonship to Joseph was understood in terms of adoption, it is correct to say that the concept of alternative family models would characterise the NT attitude to childlessness. In other words, it would have been generally understood that Christians who desired children could adopt, whilst some others might choose to be celibate, being satisfied with their membership of the family of believers. Moreover, if Paul's teaching in 1 Corinthians 7 represents the canonical recommendation for Christians, it clearly mitigates natural childbearing, and thus negates any attitude of desperation for children. This conclusion is perfectly in harmony with that on the section on the OT perspective, namely, that God gives children as a blessing but not necessarily for every individual, and its corollary that the primary purpose of marriage is companionship, not procreation. In the next section, this understanding of the biblical perspective on childlessness is applied to the Nigerian context.

\section{Implications for Nigerian Christians and the church in Nigeria}

As discussed in the opening section, Nigerian Christians' approach to childlessness has been largely influenced by desperation. Apart from seeking divine intervention in the manners described in that section, adoption and surrogate motherhood are also being used by a few to get children. However, as many have written on these methods, including the present author (e.g., Ademiluka 2019a, $2019 b)$, this section examines the implication of the biblical perspective that the blessing of children need not be for every couple for Nigerian Christians and the church in Nigeria. It must be pointed out right away that it will be an uphill task to make Africans accept any proposition of a child-free life, given their passion for children, as already indicated. Nonetheless, it is the truth that the church needs to accept and teach in the discharge of its pastoral duties. Therefore, the change of attitude and approach will have to begin with the church developing 'a theological reconstruction of the place of procreation in a theology of marriage' (Ryan 2005:72). As Ryan (2005) rightly suggests, such a reconstruction will have to mitigate the undue:

[E]mphasis on procreation as the 'fullness' or 'flowering' of marital intimacy [which] tends to render the childless marriage second class ... [It will have to shift] the emphasis on the generation of life, the acquisition of children, to an emphasis on the sustenance of life, the care of children. (pp. 72-73)

The suggestion that emphasis should be on care for children rather than child acquisition finds support in Amole (2011) when he states that Nigerian Christian couples should be made 'to understand that ... matrimony aims at parenthood but it need not necessarily end in parenthood' (cited in Ademiluka 2019a:9). In its marriage theology, therefore, the church in Nigeria has to make its members understand that 'a childless marriage remains a good marriage and retains its core and happiness' (Abasili 2011, cited in Ademiluka 2019a:9). They should be made to know, as John Paul II said, that '[E]ven when procreation is not possible, conjugal life does not for this reason lose its value' (Amole 2011, cited in Ademiluka 2019a:9).

The church's theology on marriage should incorporate emphasis on appropriate attitude that will enable childless couples to live happily even without children. Perhaps, the most crucial attitude in this regard is self-acceptance. Ryan (2005) states:

Self-acceptance is a critical moment in the spiritual journey through infertility ... $[H]$ ealing from infertility begins with a reconception of the self, the ... creation of an alternate vision of self that is not a negation, but a statement of the wholeness and fulfillment of other equally viable possibilities ... In some sense, those who successfully transcended the loss posed by infertility are those for whom the experience of infertility has become ... an occasion for giving birth to a new understanding and appreciation of the self. (p. 72)

As Muasya (2018) puts it:

$[A] \mathrm{n}$ attitude of acceptance makes one happier and more peaceful. Hence, instead of getting obsessed [with changing their condition], those with infertility ... are advised to choose to accept that fully so as to enjoy a peaceful state of mind. (p. 10)

In light of this, when the church is able to make childless couples to accept themselves as they are, they will 'find a new level of satisfaction in their marriage ... and family relationships' (CMDA 2018:19). In this regard, childless Nigerian Christians will find a good example in Mercy Oduyoye, 'the Christian scholar who had no biological children of her own but accepted her condition as an alternative Christian service' (Ademiluka 2019a:9). She testified:

I had prayed to join in obeying the command to increase and multiply, and God was saying a clear no to my offer. I felt free; I felt open and fertile, a new person for whom God has a purpose ... Rather than being consumed by childlessness, I rose like Hannah, as one who had experienced a secret 
conversation and a secret pact with God. I was pregnant with expectation of great things to come to me from God. I have not been disappointed. (Oduyoye 1999, cited in Ademiluka 2019a:9)

The church's theology on marriage should also include practical ways of assisting childless Christian couples to live happy and fulfilled lives. Concerning this, Rohlin (2006) writes:

When couples try to have children and cannot, then the biblical call to trust God means following His leading. It may mean ... choosing to live without children to free up energies for Kingdom work. (p. 1)

In the words of John Paul II:

Physical sterility in fact can be for spouses the occasion for other important services in the life of the human person, for example adoption, various forms of educational work, and assistance to other families and to poor or handicapped children. (Amole 2011, cited in Ademiluka 2019a:9)

The theology on attitude to childlessness can be contextualised in the church's various programmes and activities. As mentioned in the opening section of this work, the main activity in some denominations devoted to the childless is the monthly prayer for persons seeking the fruit of the womb. Apart from this, some churches engage intending couples in marriage induction courses to teach them how to live together in harmony. Most churches also give sermons on marital relationship during wedding ceremonies, which also usually centre on living together in peace. Now, the church will have to incorporate in all these activities the truth that companionship is the primary purpose of marriage, and not the production of children. In addition, each denomination may create other regular programmes:

$[F]$ or those who are suffering infertility ... to come together to pray and to experience the support of the community. Although many people [will] come to such a service to pray for a miracle, it also provides a context for exploring the challenge of living faithfully in the absence of miracles. (Ryan 2005:71)

Finally, this theology that marriage without children is not lacking in any way should be reflected in catechism, bulletins, magazines and all the teaching manuals of the church.

\section{Conclusion}

Infertility has been identified as a global health problem, affecting millions of Nigerian couples. Apparently derived from the OT is the belief amongst some Christians that it is God's plan for everyone to have children, and that childlessness is a punishment from God for certain sins that the barren must have committed. In Nigeria, this belief, coupled with the traditional African conception of procreation as the primary purpose of marriage, makes infertility an excruciating humiliation, particularly for women. That is why every Nigerian barren woman would go to any length to seek remedy, from the hospital to spiritual churches to traditional healing homes. However, this article found as erroneous the conception that the OT views barrenness as caused by sin, and a punishment from God. A critical examination of the relevant texts revealed that, like every other mishap, infertility happens naturally. God gives children as a blessing but not necessarily for every individual, and marriage is primarily for companionship, not procreation. In the NT, attitude to childlessness is characterised by the concept of 'alternative family models'. It was most likely generally understood that infertile Christians could adopt children, whilst some others might choose to be celibate, being satisfied with their membership of the community of believers. Paul's teaching in 1 Corinthians 7 clearly mitigates natural childbearing, and thus negates any attitude of desperation for children. For the Nigerian context, these findings necessitate a change of attitude and approach to infertility. The church has to develop a theological reconstruction on the place of procreation in marriage, in a manner that will assure Christians that a childless marriage remains a good marriage, not in any way deficient. The church's theology on marriage should encourage childless couples to inculcate the attitude of self-acceptance by which they can find satisfaction in their marriage family relationships. The theology should also include practical ways of assisting them to live happy and fulfilled lives.

\section{Acknowledgements Competing interests}

The author has declared that no competing interests exist.

\section{Author's contributions}

The author declares that he is the sole author of this research article.

\section{Ethical consideration}

This article followed all ethical standards for a research without direct contact with human or animal subjects.

\section{Funding information}

This research received no specific grant from any funding agency in the public, commercial or not-for-profit sectors.

\section{Data availability}

Data sharing is not applicable to this article as no new data were created or analysed during this study.

\section{Disclaimer}

The views and opinions expressed in this article are those of the author and do not necessarily reflect the official policy or position of any affiliated agency of the author.

\section{References}

Abasili, A.I., 2011, 'Seeing Tamar through the prism of African woman: A contextual reading of Genesis 38', Old Testament Essays 24(3), 555-573.

Abasili, A.I., 2015, 'Hannah's ordeal of childlessness: Interpreting 1 Samuel 1 through the prism of a childless African woman in a polygynous family', Old TestamentEssays 28(3), 581-605. https://doi.org/10.17159/2312-3621/2015/v28n3a3 
Ademiluka, S.O., 2012, 'Prayer against enemies among African Christians with particular reference to the Yoruba of Nigeria: A theological assessment', TheologiaViatorum: Journal of Religion and Theology in Africa 36(1), 23-49.

Ademiluka, S.O., 2019a, 'Interpreting the Hannah narrative (1 Sm 1:1-20) in light of the attitude of the church in Nigeria towards childlessness', Verbum et Ecclesia 40(1), 1-10. https://doi.org/10.4102/ve.v40i1.2004.

Ademiluka, S.O., 2019b, 'Sexual exploitation or legitimate surrogacy: Reading the Hagar narrative (Gen. 16:1-4a) in African context', TheologiaViatorum 43(1). https://doi.org/10.4102/tv.v43i1.2

Ademiluka, S.O., 2019c, 'Reading 1 Corinthians 7:10-11 in the context of intimate partner violence in Nigeria', Verbum et Ecclesia 40(1), 1-10, viewed 15 April 2019, from https://verbumetecclesia.org.za/index.php/ve/article/view/1926.

Adeyanju, A.B. \& Ayandiran, E.O., 2013, 'Health status and experiences of barren elderly women in Ondo State, Nigeria', Journal of Research in Nursing and Midwifery 2(3), 47-54.

Amole, V.A., 2011, 'Of Christianity, infertility and ethics in Nigeria', Academia, viewed 15 April 2019, from https://www.academia.edu/1438243/Of_Christianity Infertility_and_Ethics_in_Nigeria.

Asamoah-Gyadu, J.K., 2007, 'Broken calabashes and covenants of fruitfulness: Cursing barrenness in contemporary African Christianity', Journal of Religion in Africa 37 437-460. https://doi.org/10.1163/157006607X230535

Augustine, 1988 (reprint), 'On the good of marriage', trans. C. Cornish, in P. Schaff (ed.), A select library of the Nicene and post-Nicene fathers of the Christian church, Vol. 3, section 7, Eerdmans, Grand Rapids, MI.

Baloyi, M.E., 2017, 'Gendered character of barrenness in an African context: An African pastoral study', In Die Skriflig 51(1), 1-7. https://doi.org/10.4102/ids. v51i1.2172

Barth, K., 1956-1975, Church Dogmatics, G.W. Bromiley \& T.F. Torrance (eds.), Vol. 4 T \& T Clark, Edinburgh.

Baumert, N.S.J., 1996, Woman and man in Paul: Overcoming a misunderstanding, transl. P. Madigan \& L.M. Maloney, Michael Glazier, Collegeville, MN.

Berlin, A., 2004, 'Hannah and her prayers', Scriptura 87, 227-232. https://doi. org/10.7833/87-0-959

Bible Hub, 2017, 'Commentary on Genesis 30:1', Bible Hub, viewed 03 June 2018, from http://biblehub.com/commentaries/genesis/30-1.htm.

Birch, B.C., Brueggemann, W., Fretheim, T.E. \& Petersen, D.L. (eds.), 2005, A theological introduction to the Old Testament, 2 nd edn., Abingdon, Nashville, TN.

Brunner, E., 1937, The divine imperative, transl. O. Wyon, Lutterworth Press, London.

Byron, J., 2010, 'Childlessness and ambiguity in the ancient world', Proceedings: Eastern Great Lakes Biblical Society \& Midwest Region Society of Biblical Literature 30, 17-46.

Christian Medical and Dental Associations (CMDA), 2018, 'Infertility \& reproductive technology', Standards4Life, viewed 23 March 2020, from https://cmda.org/wpcontent/uploads/2018/02/Intertility-02-04-14.pdf.

Daube, D., 1977, The duty of procreation, Edinburgh University Press, Edinburgh

De-Whyte, J.P., 2014, 'Wom(b)an: A cultural-narrative reading of the Hebrew Bible barrenness narratives', PhD dissertation, McMaster Divinity College, Hamilton, Ontario.

Egede, H., 2015, 'The social stigmatisation of involuntary childless women in subSaharan Africa: The gender empowerment and justice case for cheaper access to assisted reproductive technologies?', PhD thesis, Cardiff University, Wales.

Ekeke, E.C. \& Uchegbue, C.O., 2010, 'Solving the problem of infertility among Christians: A bioethical appraisal', American Journal of Social and Management Sciences 1(2), 201-208. https://doi.org/10.5251/ajsms.2010.1.2.201.208

Fletcher, E., 2006, 'Hagar, Sarah's Egyptian slave', Women in the Bible, viewed 10 May 2018, from http://www.womeninthebible.net/women-bible-old-newtestaments/hagar/.

Holter, K., 2014, 'Pregnancy and psalms: Aspects of the healing ministry of a Nigerian prophet', Old Testament Essays 27(2), 428-443.
Jerome, O.M., 2016, 'Detachment as a prerequisite for a happy family: A study of Genesis 2:24', Mediterranean Journal of Social Sciences 7(4), 526-532. https:// doi.org/10.5901/mjss.2016.v7n4p526

Keener, C.S., 1993, The IVP Bible background commentary: New Testament, Inter Varsity Press, Nottingham, IL.

King, D.D.M., 2011, 'The marriage debate and 1 Corinthians 7', MA thesis, lliff School of Theology, Denver, CO.

Klein, J.M., 2008, 'Why scholars just can't stop talking about Sarah and Hagar', U.S.NEWS, viewed 09 May 2018, from https://www.usnews.com/news/religion/ articles/2008/01/25/why-scholars-just-cant-stop-talking-about-sarah-and-hagar.

Köstenberger, A.J., 2011, 'The bible's teaching on marriage and the family', Family Research Council, viewed 14 April, 2020, from https://downloads.frc.org/EF/ EF11J34.pdf.

Kösternberger, A.J., 2004, God, marriage, and family: Rebuilding the biblical foundation, Crossway Books, Wheaton, IL.

Levin, Y., 2006, "Jesus, "Son of God" and "Son of David": The "adoption" of Jesus into the Davidic line', Journal for the Study of the New Testament 28(4), 415-442. https://doi.org/10.1177/0142064X06065693

Loumagne, M., 2015, “'And God remembered:" Barrenness and hope in Genesis', Lumen Et Vita Journal 5(1), 1-6.

Magnuson, K.T., 2000, 'Marriage, procreation and infertility: Reflections on Genesis', The Southern Baptist Journal of Theology 4(1), 26-43.

Marriage and the Family in Africa, 1988, Unlabeled, viewed 10 June 2018, from http:// www.cormacburke.or.ke/node/288.

Mbiti, J.S., 1969, African religions and philosophy, Heineman, London.

Monroe, K. \& Monroe, P., 2005, 'The bible and pain of infertility', Journal of Biblical Counseling 23(1), 50-58.

Moss, C.R. \& Baden, J.S., 2015, Reconceiving infertility: Biblical perspectives on procreation and childlessness, Princeton University Press, Princeton, NJ.

Muasya, R.M., 2018, 'The challenge of infertility to the Christian marriage in some African societies: A plea for an ethical response in the light of Donum Vitae', American Journal of Humanities and Social Sciences Research 2(11), 4-16.

Murray, J., 1957, Principles of conduct: Aspects of biblical ethics, Eerdmans, Grand Rapids, MI

Nwosu, I.A. \& Onwe, F., 2015, 'The plight of infertile women in Nigeria', Journal of Policy and Development Studies 9(3), 39-46. https://doi.org/10.12816/ 0011165

Oduyoye, M.E., 1999, 'A coming home to myself: The childless woman in the West African space', in M.A. Farley \& S. Jones (eds.), Liberating eschatology: Essays in honor of Letty M. Russell, pp. 105-120, Westminster John Knox, Louisville, KY.

Reed, D.A., 2013, 'Paul on marriage and singleness: Reading 1 Corinthians with the Augustan marriage laws', PhD thesis, Toronto School of Theology, Toronto.

Rohlin, S., 2006, 'What is the biblical perspective on childlessness?', Probe Ministries, viewed 23 March 2020, from https://probe.org/what-is-the-biblical-perspectiveon-childlessness/?print=pdf.

Ryan, M.A., 2005, 'Faith and infertility', in Christian reflection, 65-74, The centre for Christian Ethics, viewed 22 March, 2020, from https://www.baylor.edu/ifl/ christianreflection/CloningarticleRyan.pdf.

Schones, D.A., 2019, 'Infertility in 1 Samuel 1: Toward a hermeneutic of reproduction', PhD dissertation, Southern Methodist University, Dallas, TX.

Scott, J.L., 2011, 'An examination of the barren mother stories of the Hebrew Bible', Unpublished MA thesis, The University of Georgia.

Wenham, G.J., 1987, Genesis 1-15: Word Biblical Commentary, Word Books, Waco, TX.

Wenham, G.J., 1994, 'Genesis', in D.A. Carson, G.J. Wenham, J.A. Motyer \& R.T. France (eds.), New Bible Commentary, 4th edn., pp. 54-91, Inter Varsity Press, Nottingham. 